Perspective

\title{
The psychopatholgorithm of atheism, secularism and
} satanism....

Volume 7 Issue I - 2017

\section{Perspective}

After reviewing atheism (including secularism and satanism), it is accurate to label them all as solipsistic extremists incredibly internalized and self-impressed with their absolutes of science, materialism and self. No problem with that...they can have it their way. But if true in their infallibility, atheists should not deny what religion and the Church are all about, even if there were no God. Again, atheists can have it their way if they do not want to believe or even respect religion, but they have no right to thuggishly confabulate about the Church or deform transcendental religion.

"Religion" as used in the rest of this article, means "a social organization promoting a belief system and a theory of the universe of a Loving God"- this definition thus incorrectly includes secularism, atheism and satanism. Included is "Roman Catholicism and The Church," i.e., a religion "committed to the God of Transcendental Love"- to contrast, for examples, against the calculating atheologies of "The Universe is Really Made of Numbers;"1 "We now know that the moon is definitely not there when nobody looks;"2 "There is no life force," 3 "There is no essential difference between me and notme;"4 "All believers are gullible yokels,"5 and "god, this one word: 'I'."6 Atheist conceit is usually as monumental as using the Church as a straw man to beat up all religion. Nevertheless, most atheists reveal themselves in timely fashion as did Stanislaw Kania, First Secretary of the totally atheistic Polish Communist Party, who, in 1978 upon hearing that Karol Wojtyla was elected as the first Polish Pope, could not stop exclaiming, "Holy Mother of God!"7 over and over.

Books and reviews which promote and rebut atheists are readily available as references8-42 and provide the basis for much of this article (Reviews of all these references can be requested from me at Sam@DocNigro.com).

This article is an effort to identify pathology and re-acquaint others, especially atheists and like "believers-in-nothing," with facts about most religion as a phenomenon. In this process, atheism, secularism and satanism may be identified as psychopathological nihilistic imagery promoting despair and antisocial behavior. To clarify "religion," I will focus on the Roman Catholic Church because I am most familiar with it, and I believe it offers a therapeutic paradigm of inspirational imagery for all religion including even the psychopathological imperialism of atheists et al.

Metaphors for Sane Living In Life After Death the Evidence by Dinesh D'Sousa28, the positive significance of religion is irrefutably made clear:

In my New York debate on "Is Christianity the Problem?" with Christopher Hitchens, a lively affair, against a resourceful opponentone of the most interesting questions came from a man from the island nation on Tonga. For centuries, the man said, Tonga suffered terrible vendettas, tribal wars, and even cannibalism. Then the missionaries came with their doctrines of God, universal brotherhood and the afterlife. Today, the man said, Tonga is a much more peaceful and

\author{
Samuel A Nigro M.D \\ Retired, Assistant Clinical Professor Psychiatry, Case Western \\ Reserve University School of Medicine, USA
}

Correspondence: Dr. Samuel A Nigro M.D., Retired, Assistant Clinical Professor Psychiatry, Case Western Reserve University School of Medicine, 2517 Guilford Road, Cleveland Heights, Ohio 44I I8, USA, Tel 216 932-0575, Email sam@docnigro.com

Received: March 28, 2016| Published: February 06, 2017

happy place. Then turning to Hitchens he said, "You have given us some interesting theories, but what do you have to offer us?" Hitchens was momentarily speechless (page 185).

As the Tonga people found, religion from the Roman Catholic Church offers transcendental metaphors for sane and prosocial living. These metaphors are most succinctly presented by the Catholic Mass Mantra of "Life, Sacrifice, Virtue, Love, Humanity, Peace, Freedom, Death" to be said over and over when not reciting or paying attention to the words of the priest, choir, readers and the rest of the liturgy when at Mass. Witnessed and experienced in Church liturgies are meditations for LOVE trying to promote "Everybody for Everybody!" by a rational promotion of the transcendentals of matter, identity, truth, oneness, good and beauty for everyone's life, liberty, and pursuit of happiness. The Mass Mantra and reflections for all in the Mantra are presented in the Mass, at least metaphorically, from start to finish. If one attends Mass with full embracing of all the words in the Mass, it is really quite inspiring beyond even mathematics. A case can be made that the Mass Mantra is attempted to be promoted for everyone and everything in every effort made by the official Church and all transcendental religion. The Church does not do it very well because the task is overwelming and the audience is hostile, but ecological soundness by Natural Law and psychophysiological benefit by Transcendental Love are what true religion and the Church are all about. As in the prayer (think metaphorically):

Break the bread and bless the wine and join Jesus with all others so sanctified in a Statimuum of all with all and for all Incarnated by Life, Sacrifice, Virtue, Love, Humanity, Peace, Freedom and Death in the universe received and receiving one time for all time praising God in unlimited spirituality of Consubstantiation Transubstantiation.

It is no place for cowards, the thoughtless or narcissists proclaiming lies. The metaphors are tangible and promote life, liberty and the pursuit of happiness for all, perhaps best known as "the common good." In fact, at Mass, family, neighbors, and even strangers will be looked at in the eye and wished "peace" with a handshake-Now, what in the 
world is wrong with that (except for satanists who totally dehumanize themselves by openly choosing to reject the transcendental and all related ideas42)? The Church essentially promotes the transcendentals whenever possible. That the Church does it in "the name of God" does not alter the fact that it is doing it as the only rational Natural LawFreedom-Love promoting organization in the world - the Phylum of Love, Freedom and Being against the non-being increasing entropy promoting phylum of evil. To deny this operational description of the Church is un-factual. And mentioning "God," "Jesus," the "Trinity" or any saint or religious hero, does not diminish the effort any more than do atheistic shouting, heckling, rejections, fabrications, chemical analyses, mathematical formulae or other unjustifiable maneuvers which Kierkegaard identified as obnoxious inappropriate unjustified defiance camouflaging simplistic doubt. ${ }^{43}$

Indeed, the pro-social multiple personality God "metaphor" of Three Persons, one of whom became human with us and sacrificed Himself so all could achieve a next level of existence (being), also gives a metaphorical understanding that "entropy" can have value and that the Universe itself is allegorically the material entropy necessary for the phenomenon of Love. At least metaphorically, entropic life, even when difficult, does not have to be meaningless or empty, as atheists believe and demand. In fact, it is uplifting to realize that entropy can have value when it is transcendental sacrifice.

My book, Everybody for Everybody ${ }^{44}$ contains comparable metaphorical schema ("Basic Being Realism" attached) for:

-the eightmajorspace-timevariablesofphysics(event,spectrum, field, quantum, singularity, dimension, uncertainty, and force)correspondingto -the transcendentals (the variables of all being), -mental succor (the variables of healthy human interaction), -the Sacraments and Grace (Divine variables of linkages to God),-humanbeingness (the variables of community),-virtue (the variables of will and Incarnating Acts), and -the "eight" last words of Christ on the Cross (The "earthquake" is the eighth "word").

Such religious-psychosocial concepts are allegories more than metaphors, but especially, they are rational promotions of love, humanity, peace and freedom whether one "believes" in God or not. Atheists cannot deny the space-time variables of physics but to deny personal-social analogues to physical space-time variables is to dehumanize oneself and deny reality, both psychopathological maneuvers.

"Basic Being Realism" is a template for sane living. With the Mass it offers a stress-less approach to infinity documented to be essential for health by improving neurochemistry and even immunologic integrity. ${ }^{45}$

\section{Wrong doing}

History is undeniable in Church efforts gone wrong, resisted and failed. Basically, the standards promoted by the Church are so great, that only saints can meet them. So what else is new and who/what has been perfect (except atheists et al, arrogantly omniscient in their grand fantasies and unfair distortions)? But the Church addresses wrongdoing too, even moreso than atheists and those hostile to transcendental religion. In fact, the historical Christian capital of morality lingers everywhere and can always be found in any decent civilization as the hidden strings of most all pro-social "right and wrong" formulations (In addressing "right and wrong," atheists can deny all they want, but their final formulations of "morality," or whatever they want to call it, will use the Mass Mantra rather than mathematics although they could readily use the eight basic physical space-time variables as metaphorically understood! (Excepted, of course, are satanists who are against any morality.42). And, the traditional "seven deadly sins - pride, covetousness, lust, anger, gluttony, envy, and sloth"offer undeniable templates for categorizing willful entropy and can be incorporated into Basic Being Realism as is done in Everybody for Everybody. ${ }^{44}$

When addressing wrongdoing, the metaphor of "sin as willful entropy" expands to the need for corrective action/potential, i.e., sins must be forgiven! That is, entropy can be reconceived and corrections made-i.e., "penance as entropy redirected to transcendental synthesis" is an undeniable Christian metaphor.

Thus so, the Church welcomes and is filled with sinners; and thereby the Church contains all the offensive maddening imperfections of all, but by the Sacrament of Reconciliation, the Church offers a metaphorical reality which places a person back on the, at least prosocial, "correct" sane life pathway. Thereby, personal entropy is not "fatal" because personal transitions and a future change of state ("evolution") are possible. Optimally, this inspires ideas and actions not only personally salutary but also at least for the common goodeven the common good of getting atheists to open their chemistrycontrolled (as they claim) illiberal minds.

\section{Evolution}

The Church's metaphor of "evolution" as "resurrection and eternal life" has, without recognition, preceded and is more expansive than Darwin's: However you act in this life is what will be done to you in an afterlife magnified by at least 1000 . Your every sin will be massively received "payback (entropy personalized)" in return (natural selection) --eternally if a mortal sin or in Purgatory if venial. And if in hell, there will be a never-ending infernal unstringing selfcreated self-annihilation by one's own sins now committed against oneself. And, if in Heaven, there will be a true, one, good, and beautiful ecstasy proportional to one's own transcendental life. Now that is "evolution" or the Beautific Vision or the Statimuum. ${ }^{44}$

There has always been "evolution" for the Church — an expectation of "a change of state (advancement)" and "natural selection (transcendental choice)" going beyond what is seen-to some extent comparable to the biological evolutionary progressions adamantly affirmed by scientists usually and atheists always (But, amazingly, biological evolutionists overlook the fact that the touted biological evolutionary progressions are unimaginable and unseen by the prehuman creatures involved and therefore such must naturally be beyond the imagination of and unseen by humans unless humans have a thinking ability beyond subhumans (in reality, an incontrovertible fact, thankfully). In some way, it is even against biological evolution to say "unforeseen elevating advancing progressions" stop with mankind. I have always wanted to ask Darwinists, "In the cone of space-time, how can you stop the next evolutionary leap and how can you deny it is possible?" as in The TheoGeoCalculus.45 The answer, of course, is: Like simplistic unaware subhumans, atheists are biologically hostile and defiant to extraordinary pending advancement ("evolution" beyond their simple understanding) even though revealed by elementary physics, spirituality, transcendental religion and the Church. It is one thing to realize that no creature has been able to anticipate natural selection; it is another for atheists to claim they are not in the same dull state. A real thinking being, in contrast to subhumans and atheists, can figure out that "There is more than this craziness and misery!" Religious evolution is not "survival of the fittest" but "survival of the transcendental!" In a way, evolution as currently promoted demands there be more, unless humans take 
over reproduction/genetic interaction at which time it will no longer be "evolution in Nature" but truly will be the worst "pollution against Nature" ever perpetrated, as well as against and thwarting the highly touted random basis for life's ascendancy up to now (If evolutionists believe what they claim, they would be fools to interfere with it).

Nevertheless, "Repent and get your sins forgiven" is a maddening corrective metaphor from the Church, but it is evolutionarily sound unless you unscientifically claim, "this is it" as do atheists and subhumans. So "Who needs it?" The answer is: creatures made in the Transcendental Image of God...if they want a real evolution for themselves.

Biology rebuts biological evolution ${ }^{26,47,48}$ and contemporary human "sexuality" $48,49,50,51,52,53$

Atheists do not want to know this, but agnosticism about biological evolution persists in many scientists because the same biology which allegedly proves evolution disproves it more so, if one is honest and allowed to speak freely in spite of academic inquisitions promoting materialism as bigotry and prejudice. The doubting of contemporary biological evolution is because sexuality is reproductive in nature and it is pheromone dependent-copulation will not occur among animals unless the time is right for reproduction which means no sex with the immature, no sex with other creatures with the wrong pheromones, no sex without high probability of conception and no sex for recreation (Admittedly, there are isolated exceptions because animals get mental illnesses and chemical imbalances too). But ordinarily, sexuality (copulation) in Nature is overwhelmingly chemistry dependant, (and it is inexplicable that atheists are so blind and defiant about chemically controlled sexuality when molecular explanations are demanded for everything else). Nevertheless, humans are the only creatures which are not regularly pheromone dependent for mating; and this explains why human sexuality has become almost everything except for mating. It is obvious that humans cannot be more out of synchrony with Nature than in sexuality - without biological pheromone control as in the rest of the animal kingdom, human sex has become meaningless and disordered. Without pheromones, humans choose polluting unnatural anti-planetary behavior as "sex," consistent with man's tendency to pollute thoughtlessly — but such so-called "freedom" has adverse consequences, denied and censored but real never the less even about anti-natural sex. (All human acts are really understood only by reference to Nature which determines "salutary" when in support of being or "evil" if promoting non-being.) Nature strikes back when disrespected, and without pheromone control, humans do not readily have the copulation standards of animals or Nature. Without pheromone control, humans become seduced and obsessed by glitzy degrading sex-as-recreation with meaningless unnatural squirt and slime contests ("excretory relief" most accurately called "sexcretion") all of which is just another example of humans out of synchrony with the planet again - only it feels soooo gooood that it makes us crazy even to the degree of forgetting that pheromones exist and that Nature has standards beyond gravity and chemicals.

In the final analysis, forgetting about pheromones is the cause of the theory of biological evolution itself, because evolution as currently promoted is nothing more than a projection of man's pheromone independence onto the animal kingdom resulting in a delusional denial that subhuman sexuality (copulation) is pheromone dependent. And pheromone dependency (physiological or psychosocial) means the biological theory of evolution fails because different subhuman species will not mate (never have, never will) without matching pheromones.
(To atheists' chagrin, a case can be made that the Church has been and is the psychosocial "pheromone" for mankind - by the Sacrament of Matrimony-because the Church is the only organization recognizing and promoting "sex" as primarily reproductive and life-offering consistent with, for all practical purposes, the animal kingdom and Nature.)

Biological evolution is also undone by the problem of "hybrids." Not only do major genetic transfers across different species require absence of pheromones so different species will un-naturally mate out of species, but significant evolution-required gene transfers will mandate the presence of hybrids resulting from this cross-species mating of greatly different species. But no one has ever identified any natural hybrids in nature because there is no evidence of cross species mating (or biological "miscegenation," for want of a better word). Basically, if the pheromones do not match, there will be neither mating nor hybrids.

Anti-Naturally, humans have forced hybrid creation by manipulating fairly similar species resulting in mules or tigrons, for examples. But this proves even more damaging to evolution theory because the resulting created hybrids cannot reproduce, likely because of non-matching meiosis. And if hybrids are unable to reproduce, biological evolution again just went to hell (Atheists, please pardon the phrase)!

Thus, the whole large genetic interplay and transferring required by biological evolution for cross species mating and major species creation and change is a pseudo-scientific fantasy. In nature, there is no mating without pheromone matching. There are no animal hybrids in nature. And even if they were found in nature, they will be unable to reproduce and be as sterile as artificially created hybrids. It is thus unscientific to believe in biological evolution as presented. Basically, "atheism" and "agnosticism" are more appropriately applied to current beliefs about evolution than about God or historical religion. (And, incidentally, if we humans forced our pheromoneless (non-marital/ non-reproductive) pseudo-copulative sexuality onto other creatures, it would be "animal cruelty" pure and simple and against the law just as should be the sexualization of children or immature animals.)

Pre-biological "evolution" requires a brief explanation also, and that is readily included in a universally accepted atheistic understanding of the universe: " $\mathrm{X}$ is the naturalistic result of irrational endless blobs of chemicals interacting numerically and randomly into blind purposeless forces and congeries of meaningless mechanics." Sort of takes your breath away as all are reduced to irrational nothingness by atheologies.

\section{An Example of Atheist Thinking:}

A far cry from St. Thomas' God of Pure Act, of Uncaused Cause, of Necessary Being, of Supreme Being, and of Pure Intellect, are some of today's atheist tomes. Richard Dawkins is an atheist's atheist. Here is some of his coprolallia or tour de phoney: But I was starting to tell the story of how lenses might have evolved in the first place, from a vitreous mass that filled the whole eye. The principle of how it might have happened, and the speed with which it might have been accomplished, has been beautifully demonstrated in a computer model by a pair of Swedish biologists called Dan Nilsson and Susanne Pelger. I shall lead up to explaining their elegant computer model in a slightly oblique way (pages 160-161)... The lens has "condensed" out of the vitreous mass by gradual, point by point changes in the refractory index (Page 163)...12 
The Nilsson-Pelger article (Proc.R.Soc.Lond.B (1994) 256, 5358 ), is bizarrely anti-intellectually and anti-academically distorted by Dawkins - he obviously does not think believers can read. In contrast to Dawkins' lies about it, the article was a theoretical mathematical schematization of postulated 1,829 mutations of $1 \%$ changes in 8 stages from a light sensitive flat patch to a deepened "vitreous body filled cavity" (a "camera eye") with an assumed refractory index of "1.35, which is only slightly higher than that of water and not enough to give the vitreous body any significant optical effect." Mathematical changes by the authors were schematically "introduced gradually as a local increase of refractive index". The article schematized that it would take "less than 340,000 years" for this to occur by juggling their model as they did. Basically, the article presented a model of a speculative series of sketches mathematically compounded by an imposed rate of change. There was no "elegant computer model" and the word "computer" was not even in the article. There was no condensing "out of the vitreous mass" and the word "condensed," quoted by Dawkins, is not in the article. There was no research. The article itself states that the model does not introduce structures for a functional eye such as adjustable iris; structures for distance accommodation; a vascularized layer; the choroids; retinal cells for photoreception, polarization sensitivity, and colour vision; a supporting capsule; the sclera; the blood supply; structural support; or external protective structures - none of this bothered Dawkins as he, in "delusion" as he uses the word9, claims: "The central message of this chapter is that eyes evolve easily and fast, at the drop of a hat" (page 190).12 That Dawkins is in print as a scientist is an outrage and he has proved his atheistic defiance of not only religion but of science. His ph is too low, and his "faith" in himself is too high. He is an unprincipled deceiver filled with scientific conceit and, from a religious perspective, is a leader of a contemporary "Committee of Public Safety" i.e., this time, a bunch of scientists and liberal editors ready to relive the French Revolution. (I have complained to Oxford University several times about Richard Dawkins being a fraud of science, but he apparently still remains in good standing on the faculty - think what you will about the alleged illustrious reputation of Oxford University).

(And by editor imposed unconstitutional illegal prior restraint, the liberal press and media censor my right to a free press about all this, as liberal editors continue to mislead the people by suppressing and censoring the truth that Dawkins is a pseudoscientific lying flagrant fabricator. Being an atheist has its advantages but even Church-hating atheist emperor wannabees and totalitarian editors and producers usually know the truth and are obligated to promote it even when counter to their own faithlessness. Because atheism and contemporary evolution are protected religious myths, the First Amendment becomes a joke, because the liberal editors of the pressarchy in charge do not allow equal livability of free speech, free assembly, free press and free exercise for all citizens - because truth from citizens is excluded by the so-called "free press." News is not news unless the editor says so - and the First Amendment is, as stated, a joke on the people.

Also, psychiatrists know that fabricators are often brain damaged, but I hope in this case that Richard Dawkins and other atheists like him are not brain damaged but are just wrong in their dogmatic imperialistic efforts, which, hoist with one's own petard, are typically worse than the Church's dogmatisms ever were. To everyone: Be careful of what you believe from atheists - like subhuman animals, they cannot understand or believe in more than themselves - and liberal editors, along with Hollywood celebrities,54 are the worst. Atheism et al are psychopathogies.)

\section{What is Entropy?}

So, as the only "pheromone" provider for humans to be consistent with Nature, as agnostic about the secular evolution belief system, but with the Mass Mantra of "Life Sacrifice Virtue Love Humanity Peace Freedom Death" and with "do not be or increase entropy by sin," the Church dares to tell people what personal entropy is, i.e., what sins are! Entropy is wasted energy; sin is willful entropy, and no one wants to hear how they are wasting their lives when entropic. Indeed, telling people they are wrong makes people more crazy than sex or money, especially atheists, even though atheists call religious people "wrong" by an extravagant presumptuous dogmatism based on distortions and denial of history more than the Church ever did or does. It seems that when it comes to wrongdoing, people, atheists in particular, tend to want a cult of nihilism - nothing matters and nothing is wrong except disagreement with them. Somehow, today's culture makes people place their personal energy into one of the following categories: niloisie (nothing), sexoisie (squirt/slime), booboisie (ignorance), or, best, anti-entropic loveoise.

Regardless, the outcome of past atheism has been the worst entropy-Communism, Naziism, Fascism, Islam (after Mecca I) and any implemented Godless secularism, all prove that evil is willful entropy - which occurs more without, than with, God. The sins of Rome pale to the sins of atheism. Still the Church is surrounded by vulgar hate and shameless hostility - most likely due to "rationalized guilt" in loud deniers not wanting to hear that "sin has consequences" (Ask Tiger Woods, but not Richard Dawkins--yet). So, many dislike the cogent and irrefutable Church lovingly telling us how and when we are transcendentally wrong. They will make the Church pay for getting under their skin by pointing out their entropy.

Nevertheless, an accurate understanding of the sin metaphors of the Church is to see sin and forgiveness of sin as enhancing of the common good as much as are the Church's promotions of virtue. Any person wanting the common good would hope the Church's metaphors never change even though they make us feel bad! By following the Church, personal entropy is resynthesized and converted to transcendence by the Sacraments and Grace - there is no more wasting or polluting. The metaphors that "evil is the promotion of entropy" and "you can do something about it" are for the Common Good and uplifting.

\section{Against the Church}

Believers feel overwhelming therapeutic ecstasy as participants in the Church's efforts to promote "everybody for everybody" especially when the Church enables synthesis (as appropriate forgiveness) even while impeccably, irrefutably, rationally telling us what we are doing wrong. But chronic Church criticizers and especially atheists deny the transcendentals in order to feel otherwise. To read and listen to the outrageous dishonest emotional criticisms of and exaggerated accusations against the Church are bewildering and disgusting proof of the metaphor of Original Sin i.e., humans are pathologically entropy suggestible - we can be suggested to believe and do anything when the transcendentals are ignored-Most simply, it is called "advertising" from junk food to junk ideas. The brainwashing anti-Catholicism so persistent is the low key continuation of World War II Japanese Bushido Code and Goebbels' Nazism. A regular example is "My books are about killing God...I'm trying to undermine the basis of Christian belief'55 -and the current cultural theophobia, dehumanization and depersonalization are undeniable and psychopathic. Atheists cannot stand the Church for self-serving and evil reasons, and the following is an attempt to understand the irrational hatred and the psychopathological theophobia and anti-Catholic bigotry. 
i. "God" causes loss of self. Nowhere is this more true than Ayn Rand with her "Virtue of Selfishness". All one needs to understand of Ayn Rand is in The Bad Catholic's Guide to The Seven Deadly Sins by John Zimark Pgs. 211-215.

ii. Atheists must defend themselves by extreme emotional attacking.

iii. Atheists selectively condemn ignoring their own misdeeds and those of their allies.

iv. Atheists are totalitarians and experts of suggestibility/gullibility.

v. Atheists have delusions of nihilism and live in essentially of cruel nothing but themselves.

vi. Atheists pretend a numerological expertise to rationalize their thinking and contentment.

vii. Atheists always project their belief that death is better than spirit.

viii. Atheists tend to be squirt/slime sex obsessed, dirty old men.

ix. Atheists associate wanting all to feel bad or else.

Atheists externalize all wrong doing to achieve their god-selves consistent with Ayn Rand's thinking.

Maybe "irrational hatred" is actually the only way to understand that atheists and Church criticizers usually have no spirit - they have no evolutionary anticipation (a good definition of "spirit") for themselves - they only have their solipsistic selfishness imposed in a most unfree, irrational, dogmatic fashion far surpassing any Church dogmas. In fact, a case can be made that almost all the alleged misdeeds of the Church can almost always be most vividly seen as mythical obsessions or hateful magnifications - the lasciviousness of nuns, the scheming of Jesuits, the pedophilia of priests, the protecting of Nazis, the so-called terrible Inquisition, the "superstitious" Middle Ages, the alleged antiscience about Galileo (the world's most famous plagiarizer, p.33556) and others, the provocative Crusades, the so-called laundry slaves of Irish nuns, the whore of Christendom, or any other bogus distortions, besmirching harangues, unfair caricatures, alleged prejudices and Church based misdeeds against anyone-whatever, the alleged deeds and sins of Rome are almost always totally exaggerated or fabricated and in fact ironically actually perpetrated more by the loud condemners themselves than by the accused Church — and that applies to the incredible arrogant totalitarian dogmatism of atheists which is typically more oppressive than the worst descriptions of old-fashioned loud churchmen. Contemporary Church condemners constitute a real "Dark Age" today of meretricious scholarship, disingenuous history, celebrity fakery, and primitive thinking.56 In fact, the real creators of the "dark" for any historical age have been found to be humanists (who basically are pre-atheists or closet satanists) — both living and dead (p. 210 and p. 219). ${ }^{56}$

(After reviewing the Inquisition57, for any ruling concerning myself, I would prefer any judge of the 300 year Inquisition to $90 \%$ of current USA judges and no judging at all from liberal editors, liberal commentators and gaseous internet-television-movie producers, all of the latter provoking the neologism: ""pamce"' i.e,. a noun meaning "a person made into a dunce by the press and media-never more proven for editors and readers than by the 2009 Cleveland Plain Dealer's censorship of "God" from a front page article about a surgical operation on an evangelical child57 which reminds that "plain dealing" was what Oliver Cromwell said he was doing when he murdered thousands of Irish Catholics, no doubt well understood by the many Irish immigrants flooding Cleveland when the Plain Dealer was founded in 1842. The press and media, including even The History
Channel, are a disgrace when it comes to "religion" especially about the Church. And finally, the judges of the Inquisition only wanted the Truth, and, in addition, the capital punishment rate of the US today is 20 times that of 300 years of the Inquisition-History is truly bogus when it comes to the negatives about the Church.)

In closing, atheists would appear to be proving original sin: that all are suggestible/gullible to be hateful, or against being, about something, even hateful about an organization which, when fairly and accurately appraised, is for Love..."everybody for everybody"... Truth, Oneness, Good and Beauty for everyone's Life, Liberty and the Pursuit of Happiness... with gentle Peace, empathic Justice, and gentle Mercy for everyone's sake - sanity, while, in a civilized society, all else tends to be psychopathology - from simple irrational denial to emotional delusions to psychopathic nihilism.

\section{Conclusion}

Perhaps the Theory of General Sacramentality is helpful for atheists and secularists (nothing can be helpful for satanists who choose to reject all but non-being) :

$$
\begin{aligned}
& \mathrm{Sa}+\mathrm{St}=\mathrm{iaT}+\mathrm{aaS}+\mathrm{iaV} \\
& (\mathrm{D} x(\mathrm{dd}) 2)+(\text { sin) aiy }
\end{aligned}
$$

where Sa is Salvation; $\mathrm{St}$ is Statimuum; ia is ideas-actions; $\mathrm{T}$ is Transcendentals; $\mathrm{S}$ is Sacraments; $\mathrm{V}$ is Virtue; $\mathrm{D}$ is dumbo, the atheism constant; dd is the damnation distance from God; sin is sin; and aiy is the person's age in years. For completeness, readers should know that the Theory of Specific Sacramentality can be found in the Baltimore Catechism, The Catholic Encyclopedia, and The Encyclopedia of Catholic Social Thought, Social Science and Social Policy.)

Or, maybe, my father's frequent Italian originate is the best panCatholic summary of all: "No heart, no mind" reminding of the 800 times the word "heart" is in the Bible as a reference to "love." No atheist could do as well. And it is doubtful that any atheist or secularist can quantify their remedial guilt...as my own mother who would weep in remorse whenever reminded of her Protestant childhood vis a vis the only Catholic family in her small central Kansas town: "We all treated them terribly...I cannot believe how terribly we treated them..." and she would shake her head and change the subject. It is pathological —it is psychopathologic — not to understand.

The psychopatholgorithm is as follows: Induced/biochemical SELF-PITY, however developed, kills the self to NO-MEANING which means NO EMPATHY. The resulting "Hate your neighbor as yourself" converts to DESPAIR acted out as HATRED OF ALL BEING and the choosing of atheism, secularism and even satanism. Despair is nurtured instead of the mantra of "Life, Sacrifice, Virtue, Love, Humanity, Peace, Freedom, Death."

\section{Acknowledgments}

None.

\section{Conflicts of interest}

None.

\section{Funding}

None.

\section{References}

1. Shing Tuan Yau in Discover Magazine. 2010. 
2. Harvard-Cornell physicist David Mermin in Philosophical Consequences of Quantum Theory. 1989. p.50.

3. Steven Weinberg. A Designer Universe. 2007.

4. John Allen Paulos. Irreligion: A Mathematician Explains Why The Arguments For God Just Don't Add Up. Hill and Wang, USA. 2008. p.1-176.

5. Christopher Hitchens. God is not great: How Religion Poisons Everything. Twelve, USA. 2007. p. 1-336.

6. Ayn Rand, Anthem.

7. John O'Sullivan. The President, the Pope and the Prime Minister: Three Who Changed the World. Regnery Publishing, USA. 2006. p.1-55.

8. Steven Weinberg. A Designer Universe. 2007.

9. Richard Dawkin. The God Delusion. Bantam Press, UK. 2006. p.1-398

10. Richard Dawkins. The Selfish Gene. Oxford Press, USA. 1976. p.1-385.

11. Richard Dawkins. The extended phenotype. Oxford University Press, USA. 1982. p.1-287.

12. Richard Dawkins. Climbing Mount Improbable. 1992.

13. Sam Harris. Letter to a Christian Nation.2006. P.1-31.

14. Sam Harris. The End of Faith, Religion, Terror, and the Future of Reason. W. W. Norton \& Company, USA. 2006. p.1-352.

15. Daniel CD. Breaking the Spell: Religion as a Natural Phenomenon. 2006. p.1-391.

16. Michel Onfray. Atheist Manifesto: The Case against Christianity, Judaism and Islam. Melbourne University Press, Australia. 2007. p.1-219.

17. A Humanist Manifestos I (1933) and II (1973).

18. Daniel J Flynn. A Conservative History of the American Left. Crown Forum, USA. 2008. p.1-464.

19. David Belinski. The Devil's Delusion: Atheism and its Scientific Pretensions. Crown Publishing Group, USA. 2008. p.1-258.

20. Anthony Flew. There is A God: How the World's Most Notorious Atheist Changed His Mind. HarperOne, USA. 2007. p.1-26.

21. David Stove. Darwinian Fairytales: Selfish Genes, Errors of Hereditary and Other Fables of Evolution. Ashgate Publishing Company, USA 1995. p.1-233.

22. Thomas Crean OP. God is No Delusion: A Refutation of Richard Dawkins. 2007.

23. Benjamin W, Jonathan W. A Meaningful World: How the Arts and Sciences Reveal the Genius of Nature. Inter Varsity Press, USA. 2006. p.1-252.

24. Bethell T. The Politically Incorrect Guide to Science. Regenery Publishing, USA. 2005.

25. Johnson P. Creators. 2006.

26. Bonnett D. Origin of the Human Species. The Catholic University of America Press, USA. 2007.p. 1-266.

27. Hart DB. Atheist Delusions: The Christian Revolution and Its Fashionable Enemies. Equinox Publishing Ltd, UK. 2009. p.1-4.

28. Warren R, D’Souza D. Life After Death The Evidence. Regnery Publishing Inc, USA. 2009. p. 1-256.

29. Rieff P. My Life Among the Deathworks. 2006.

30. Overman DL. A Case for the Existence of God. Rowman \& Littlefield Publisher, UK. 2009. p.1-35.

31. Behe MJ. The Edge of Evolution: The Search for the Limits of Darwinism. 2009.
32. Dembski WA, Wells J. The Design of Life: Discovering Signs of Intelligence in Biological Systems. Foundation for Thought and Ethics, USA. 2008. p.1-7.

33. D'Souza D. What's So Great About Christianity. Regenery Publishing, USA. 2008. p.1-20.

34. Hutchinson RJ. The Politically Incorrect Guide to the Bible. Regenery Publishing, USA. 2007.

35. Schooyens M. Bioethics and Population: The Choice of Life. Central Bureau, USA. 1996. p.1-112.

36. Sweetman B. The Failure of Modernism: The Cartesian Legacy and Contemporary Pluralism. Catholic University of America Pressm, USA. 1999. p.1-9.

37. Russell Hittinger (2003) The First Grace: Rediscovering the Natural Law in a Post-Christian World. Catholic Social Science Review, p. 1-4.

38. Pitstock C (1998) After Writing, On the Liturgical Consumation of Philosophy. Religion \& Literature 31(2): 111-116.

39. McGowan K. Sins: Science is Looking Inside the Brain to Untangle the Roots of Our Bad Behavior, Discover Magazine. 2009.

40. Samuel A Nigro. Review of The God Delusion by Richard Dawkins in Social Justice Review. 2007. p.1-190.

41. Samuel A Nigro. Review of A Small Treatise on the Great Virtues by Andre Comte-Sponville, 1996 in ProEcclesia Magazine. 2005;36:1-24.

42. Richard W. Marx \& Satan. 1986. p.1-79.

43. Kierkegaard S. Journals, 1847, quoted in Walter Lowrie, Kierkegaard. 1938;1:1-187.

44. Samuel A Nigro. Everybody for Everybody: Truth, Oneness, Good and Beauty for Everyone's Life, Liberty and Pursuit of Happiness Volumes II: Volume II. Xlibris, USA. 2011. p.1-804

45. Raison CL. Inflammation and Mood Disorders. Audio Digest Psychiatry. 2011;40(5).

46. Samuel A Nigro. The Theogeocalculus of Life: Natural Law Has the Answer to Everything. The Linacre Quarterly. 2006. p.1-18.

47. Samuel A Nigro. Charles Darwin's Bicentenary, Time for A Celebration... or An Inquest? Social Justice Review. 2008. p.72-76.

48. Samuel A Nigro. Why Evolutionary Theories Are Unbelievable. The Linacre Quarterly. 2004;58-63.

49. Samuel A Nigro. Stop Sex Education and Start Marital Education. Social Justice Review. 1998;181-185.

50. Samuel A Nigro. Same Sex Marriage. Social Justice Review. 2004;1-99.

51. Samuel A Nigro. Marriage and Homosexuals. Social Justice Review. 1997;56-57.

52. Hildebrand AV. Man and Woman: A Divine Invention. 2010.

53. Adams M. Feminists Say the Darndest Things. 2007.

54. Samuel A Nigro And Satan Turned Into An Angel of Light,

55. Pullman P. His Dark Materials: The Golden Compass, The Subtle Knife, and The Amber Spyglass. 1995.

56. Hannam J. God's Philosophers: How the Medieval World Laid the Foundations of Modern Science. Australian eJournal of Theology. 2009:16(1):1-2.

57. Samuel A Nigro. Review of The Spanish Inquisition: A Historical Revision, by Henry Kamen, in Social Justice Review. 1999. p.62-63.

58. Kevin, Malarkey A. The boy who came back from heaven: A remarkable account of miracles, angels, and life beyond the world. Tyndale House Publishers, USA. 2010. p.1-240.

59. Viktor F. Man's Search For Meaning. Beacon Press, USA. 1946. p.1-148. 